DOI 10.14746/ssp.2018.4.3

Asad TAFFAL

An-Najah National University in Nablus

ORCID: 0000-0002-7883-0886

\title{
Europe and the Syrian Refugees: Challenges and Opportunities of a Dilemma
}

\begin{abstract}
Since the beginning of the war in Syria, massive numbers of Syrian citizens have fled their homeland to escape death and secure a better life for themselves and their children overseas. The Syrian refugees have sought asylum in many countries, although Europe was their main destination. These vulnerable families crossed rivers, mountains and plains and faced every danger imaginable to reach Europe; many died along the way. Heading toward the unknown, the refugees had little to no expectation of what they were going to face where they were heading. But for them, going back is not an option. On the other side of the equation, the European countries were also under substantial pressures to receive and deal with the refugees. The European countries' reaction and response to the refugee movement varied significantly, with some countries, such as Germany, welcoming and receiving large numbers of Syrian refugees, and others, such as France, the Czech Republic and the UK, being more reluctant to openly welcome them. In this article, the European states' approach to dealing with the Syrian refugee crisis and the challenges they currently face will be discussed and explained in light of the events on the ground. This article deals with the issue of the relationship between the Syrian refugees and the European countries in terms of the efforts that Europe has made to help these refugees, as well as the impact that the refugees have had or will have on various aspects of life in Europe.
\end{abstract}

Key words: Syrian Refugees, European Union, Migration, Asylum, Crisis, Civil War

\section{Introduction}

\begin{abstract}
lmost everyone today agrees that the Syrian refugee crisis is con$A$ sidered one of the biggest and most problematic in all of human history. The scale of devastation and death in Syria is almost unheard of. According to Amnesty International, around 220,000 people have been killed and 12.8 million people are in urgent need of humanitarian assistance inside Syria, and more than $50 \%$ of Syria's population is currently displaced (Amnesty International, 2015).
\end{abstract}


Forced to leave their country, the Syrians sought asylum in many neighboring Arab countries, such as Jordan, Iraq, Lebanon and Egypt, as well as several European countries, over the course of the crisis which started almost four years ago. Many Syrian refugees headed towards Europe, crossing several countries on foot and on boats, risking their lives in the process. They battled their way across Turkey, Greece, Bulgaria, Hungary, Austria, Switzerland, and Italy, among others. More than 920,000 migrants are estimated to have arrived by sea alone so far in 2015, according to the International Organization for Migration (IOM), but exact numbers are unclear as some may have passed through borders undetected.

When they first started moving towards Europe, the refugees did not have any idea of what they were going to face and what sort of challenges and difficulties were waiting for them overseas. However, since they had no choice, their only way to escape death was to risk everything and leave.

Of course, the European states' response to the huge waves of refugees varied from one country to another, with some countries, such as Germany, welcoming the largest numbers of Syrian refugees, whereas others, such as France and the UK, showed more reluctance toward the idea of openly receiving the refugees. Germany continues to be the most popular destination for migrants arriving in Europe. It has received the highest number of new asylum applications, with more than 315,000 having arrived by the end of October. Hungary has moved into second place, as more migrants have tried to make the journey overland through Greece and the Western Balkans. It had 174,055 applications by the end of October 2015 (Migrant Crisis, 2015).

The number of migrants reaching Europe by boat has risen dramatically in 2015, compared with the same period in 2014. The number arriving in Greece, in particular, has soared. The EU's border agency said that almost 50,000 migrants arrived on the Greek islands in July alone, most of them Syrians. The number of migrants reaching Greece by sea had reached 158,000 by mid-August, according to the UN, overtaking the 90,000 who arrived in Italy by sea (Why is EU Struggling with Migrants, 2015).

In this context, this research aims to shed light on how countries view the Syrian refugees and their plight, and what economic opportunities and advantages they may offer to host countries. To achieve the purpose of the research, it is important to explain that, although several European countries, such as Austria, Sweden, Denmark and others, did show 
a considerable degree of support and hospitality to the Syrian refugees, Germany was the most prominent example in this regard, since it not only welcomed the refugees, but also took advantage of their skills and expertise in various areas of life and integrated them into German society, as indicated by the data contained in the research. Furthermore, the research presents some of the top questions asked about the Syrian refugees on Google, as shown through Google Trends.com, as well as what questions the various European countries had about the refugees.

\section{Europe's reaction to the crisis. Governmental level}

Although the Syrian refugee crisis is in itself a very sad story, one cannot look at this issue from one perspective only. In order to understand the crisis, one should look at it from the perspective of both the refugee and the host. While it is true that the Syrian refugees had no choice and were forced to leave their country in their millions, it is very important to remember that many European countries already had their fair share of internal crises and problems, relating to the economy, space, employment, residency, education, housing, food and so on. Some countries, such as Greece, had a very weak and unstable economy, and the refugees coming to it meant that the country could not accommodate the large numbers of people flooding in. Others, such as Hungary had a refugee-to-population ratio crisis, i.e. the surge of people arriving in Hungary meant it had the highest in proportion of refugees relative to its population. More than 1,450 refugees per 100,000 of Hungary's local population claimed asylum in the first half of 2015 (ibid.).

For years, the EU has been struggling to harmonize its asylum policy, which is difficult with 28 member states, each with their own police force and judiciary. Championing the rights of poor migrants is difficult, as the economic climate is still gloomy, many Europeans are unemployed and wary of foreign workers, and EU countries are divided over how to share the refugee burden. The number of asylum claims in the EU rose to 626,065 in 2014, up from 435,190 in 2013, the European Commission reports; Germany granted the most, followed by Sweden and Italy (Why is EU Struggling with Migrants, 2015). The waves of refugees hit the European shores fast and left the European countries overwhelmed by the sheer numbers of people coming in. 
It is easy to overlook the reality of life in Europe and the hidden problems there, since the sparkling image of the continent often hides the challenges that Europeans face in their own countries. People from outside of Europe often think of it as a land of unlimited opportunities and a wealthy life, which is true to some extent, but European countries also have their own problems in their economies, social life, education and employment, as pointed out above. Therefore, receiving more people into their lands in the form of huge waves of refugees meant that European people are now facing greater problems and challenges.

Some countries, such as Hungary, were alarmed by the huge numbers of Syrian refugees flooding in from the Middle East. They responded to the crisis with force and opposition. The measures that Hungary is currently enforcing with utmost ruthlessness - the construction of a border fence, the use of tear gas and the army against refugees, their internment in camps in deplorable, unhygienic conditions - have long been practiced elsewhere (Schwarz, 2015).

Although the European Union has allocated significant funds to help the refugees and manage the crisis, these funds were not used appropriately. Between 2007 and 2011, the EU provided its member states 2.2 billion euros for refugees, but only a fraction of this amount has gone towards their accommodation and integration. Around half of the money, one billion euros, has flowed into border protection: the construction of fences, surveillance and controls (ibid.). This clearly indicates the level of fear and concern among the European countries toward the Syrian refugees.

Three years ago, Greece and Bulgaria, supported by the EU, constructed a high-tech fence, guarded by an army of police officers, to seal their borders with Turkey. The fence has forced hundreds of thousands of refugees to undertake the perilous route through the Mediterranean, with thousands subsequently dying at sea. The Spanish enclave of Ceuta is protected by a six-meter-high fence, in which refugees are repeatedly trapped and die like fish in a net (ibid.).

\section{Europe's reaction to the crisis. The individual level}

Of course, the reaction towards the Syrian refugee crisis did not only come from governments and officials; different Europeans exhibited different reactions and opinions toward the issue. 
The response to the refugee crisis varies significantly among people in Europe, according to the questions they ask on Google. There are key differences in what the top search questions about 'migrants' are across Europe, with people in the UK, France and Germany all reacting differently. Questions relating to the definition of the terms 'migrant' and 'refugee,' where they are coming from and what people can do to help are all popular searches, according to data released by Google Trends (Kirk, 2015).

Interest in the refugee crisis has spiked recently - with Germany dominating searches related to the topic. This coincides with the country's decision to temporarily reinstate border controls in order to deal with the influx of people arriving (ibid.).

The top five questions Googled about 'migrants' in each European country between February $19^{\text {th }}$ and $26^{\text {th }} 2017$ reveal interesting differences - with people in Germany, Hungary and Italy seeming more willing to help than British, French or Greek people (ibid.).

\section{What is Europe asking about 'migrants'?}

\section{United Kingdom:}

1. What is the difference between a migrant and a refugee?

2. What is an asylum seeker?

3. What is an economic migrant?

4. Why is there a migrant crisis?

5. How many people attended the migrant march in London?

\section{Germany:}

1. Where are the refugees coming from?

2. How can I volunteer to help migrants?

3. Why do migrants go to the UK?

4. When is a refugee really a migrant?

5. What will happen in Europe after the migrant crisis?

\section{France:}

1. What does the European migrant crisis mean for travelers?

2. What are the Somalian refugees fleeing from?

3 . What is a migrant advocate?

4. What is a migrant?

5. What is the migrant situation in Europe now?

\section{Hungary:}

1. How should Christians respond to the migrant crisis? 
2. What happens to refugees without passports?

3. Where did Aylan Kurdi's body wash up?

4. How many migrants does Germany have?

5. Where are migrants distributed globally?

\section{Sweden:}

1. What is the definition of a migrant?

2. What is an asylum seeker?

3 . Is the migration issue an invasion?

4. How much money do migrants send home?

5. How many refugees do Sweden take in each year?

\section{Greece:}

1. Why is it called a migrant and not a refugee crisis?

2. What is the solution for the migrant crisis?

3. What is a migrant?

4. What does Germany stand to gain from the migrant crisis?

5 . What is the definition of a refugee?

\section{Austria:}

1. How many migrants are there in Europe?

2. What is the Syrian government doing about the migrant situation?

3. Who is the Hungarian woman kicking migrants on TV?

4. How long will the migrant crisis last?

\section{Italy:}

1. How can I adopt a Syrian orphan child?

2. How many migrants are there in Italy?

3. How can a migrant get from Greece to Germany?

4. Will Germany accept a migrant who has given fingerprints in Italy for now?

Questions that people in the UK ask about the refugee crisis reveal anxiety and confusion about the issue, with the top questions including "Why is there a migrant crisis?" and "What is the difference between a migrant and a refugee?"

There is little interest in helping to ease the situation - unlike in Germany, where the top two questions are "Where are the refugees coming from?" and "How can I volunteer to help migrants?" (ibid.)

In Hungary, the top question on Google is "How should Christians respond to the migrant crisis?," while people in Italy have been asking "How can I adopt a Syrian orphan child?"

This contrasts with their government's harder lines, such as Hungary's decision to close its border to refugees. People in France, on the other 
hand, seem more concerned about how the refugee crisis will affect their travel plans, with the top question in the country being "What does the European migrant crisis mean for travelers?"

The data from Google Trends reveals varied reactions to the thousands of refugees seeking a home in Europe, with a significant proportion of questions simply trying to understand the crisis.

According to Kirk, among the 21 countries surveyed, the most popular questions were "what is a migrant?," "what is the difference between a migrant and a refugee?" and "what is the definition of a migrant?" Google searches also revealed anxiety about the refugee crisis and what Europe can do to help (Kirk, 2015).

Clearly, the positions and reactions toward the Syrian refugee crisis were very different. This is due to the fact that people in the different European countries were looking at the issue from different angles depending on the situation in their own country. Some people were afraid that the refugees will end up taking all the jobs and flooding the European job market, whereas others were more concerned about the safety of their own societies, especially taking into consideration the fact that the majority of Syrian refugees are Muslims and Islamophobia in the West is prevalent.

Concerns like these are somehow justified if one looks at the situation from the viewpoint of the host country and its people. There are reasons for Europe's hesitation to take them: a lack of capacity to handle thousands of asylum seekers, for instance, and security concerns, particularly in the aftermath of the Paris and Copenhagen terrorist attacks in early 2015. But some of the opposition is more nationalist and cultural in flavor. In the Czech Republic, Poland, and Slovakia, thousands of protesters have flocked to demonstrations, opposing migration and chanting anti-Islamic slogans. Banners read GO HOME and ISLAM IS DEATH. Hungary's Prime Minister, Viktor Orban, has opposed accepting Muslim refugees on religious and cultural grounds, citing his country's occupation by the Ottoman Empire in the 16th and 17th centuries. Slovakia, similarly, has decided to only accept Christian Syrians (Proctor, 2015).

As was mentioned earlier in this article, the level of concern and fear among Europeans is very high and diverse. However, there are other aspects of the crisis that need to be explained and discussed in order to give a clearer picture of the whole situation. 


\section{The other side of the refugee crisis}

Despite the fact that the Syrian refugees have had a rapid and significant impact on the European continent, leading many European people and governments to show concern for the safety and security of their societies, the fact that large numbers of refugees are middle class might present a great opportunity for Europe.

But what could possibly be good in a refugee crisis? How can a host country benefit from refugees and in what manner? What are the current weaknesses and problems that the European countries have that might be solved by the refugee crisis? The Syrian refugee issue is a very serious one indeed, and could potentially have undesirable effects on the whole continent. But, in this current atmosphere, too little is made of the opportunity presented by the migrants and refugees heading to Europe by train, truck, and raft. Among the refugees attempting to get in are the remnants of Syria's middle class: doctors, engineers, and teachers fleeing Assad's barrel bombs in Aleppo, or the reign of terror ushered in by Islamic State. They could bring vitality and opportunity to an aging European continent that badly needs it (ibid.).

According to the European Commission, the 'graying' of Europe is among the EU's most serious social and economic challenges. More than one-fifth of Europeans will be 65 or older by 2025, placing great strain on social services and health care (ibid.).

Integrating young migrants could provide a much-needed demographic boost, and unlike Jordan, Turkey, or Lebanon, Europe has far more resources to integrate them. As reported by $\mathrm{CNBC}$, Pierre Moscovici, the European Commissioner for Economic and Financial Affairs, has stated that the current migration and refugee crisis should not just be seen in terms of cost, but opportunity (ibid.).

"It is also a resource - a human resource," Moscovici said. "Our countries need migration... the economic impact should not just be looked at in a negative way as populists would have it" (ibid.).

If Europe succeeds in taking advantage of the refugee crisis in a constructive and positive way, it will be of benefit both to itself and to the refugees. By welcoming the refugees and providing them with jobs and places to live, the European countries will be making a long-term investment that will bear substantial fruits in the future, leading to a much faster recovery in Europe's economy and social life.

According to the Financial Times, Wolfgang Schäuble, Germany's Finance Minister, takes a similarly warm view: the short-term costs are 
manageable, while the long-term benefits are potentially substantial. Migrants are, generally, a boon to labor markets. Moreover, they pay out more to the state than they take in services, according to separate pieces of research by the OECD and the Centre for European Economic Research. In light of Europe's anemic economic recovery, the current refugee crisis, while founded in misery, may be vital to the EU's future (ibid.).

The common misconception that refugees are a burden to host states is a dangerous trope that has emerged in Europe's present refugee crisis. It distorts the reality of the situation, while promoting both disdain and inaction. "These arguments are often advanced without recourse to evidence. Indeed, few economists have worked on refugees and forced migration, and governments do not have disaggregated immigration data that can show the economic impact of hosting refugees," Professor Alexander Betts, Director of the Refugee Studies Centre at Oxford University told World Finance (Matsangou, 2015).

In Betts' 2014 study titled Refugee Economies: Rethinking Popular Assumptions, it was found that the presence of refugees boosts a local economy significantly as a result of additional purchasing power, the creation of employment and the provision of human capital. "Refugees around the world engage with markets. Even in the most restricted circumstances of closed refugee camps and without the right to work, economic activity can be observed. Refugees engage in consumption, production, exchange, entrepreneurship and the development of capital markets. Much of our research suggests that whether refugees are a benefit or a burden depends not just on who the refugees are, but also on the policies of the host states. When they are given the right to work, access to capital, and educational opportunities, they are likely to have the greatest impact," Betts explained (ibid.).

The research conducted by Betts and his team took place in Uganda, as the right to work and move around freely for refugees is markedly better there than in neighboring countries. "One of our most striking findings was the entrepreneurship of refugees. Faced with new markets, new social networks, and a new regulatory environment, people adapt even faced with significant constraints," said Betts. "In Kampala, the capital city, for instance, we found that 21 percent of the refugees have businesses that employ other people and 40 percent of those employees are citizens of the host country. In other words, refugees were creating jobs. Many of the businesses were, even in refugee camps, highly innovative and networked into the structures of the global economy" (ibid.). 


\section{Germany as an example}

Of all the European countries, Germany, as explained earlier in this article, was among the countries that welcomed the largest number of Syrian refugees. By looking at the situation and Germany's position toward the refugee crisis, one cannot fail to notice that the Germans had a long-term vision and had been planning ahead.

Aside from a well-known record of accepting asylum seekers, in September, Chancellor Angela Merkel announced that Germany would open its arms to at least 800,000 refugees in 2015. There is, of course, the humanitarian element involved in this welcome, because helping those in dire need is 'the right thing to do.' There is also another angle, which has allowed Merkel to make the somewhat bold move; the influx of refugees can be extremely advantageous for Germany's aging economy (ibid.).

A recent study conducted by Hamburg's World Economy Institute found that Germany's birth rate is now the lowest in the world and is declining faster than any other industrial country. According to immigration researcher Herbert Brücker in an interview with Deutsche Welle in 2014, around 1.5 million skilled immigrants are needed to sustain Germany's state pension system; it is estimated that by 2060 , two workers will be needed to support every retired person in Germany (ibid.).

Germany is a good example of what countries should do in order to fulfill their human responsibility on one hand, and taking advantage of the crisis to solve their local problems on the other. The process of accepting and integrating refugees into society is not easy and requires the introduction of a significant number of developments and changes to many aspects of life in the host country. To facilitate this, institutions such as The Confederation of German Employers' Associations (BDA), offer businesses assistance in order to integrate refugees into the market legally and effectively. Dr Carmen Bârsan, advisor for the Labor Market Department at the BDA, explained the complex and lengthy process; "[f]irst of all, we think it is very important to create effective labor market access for these people" (ibid.).

"Another important point is that successful integration in the labor market requires acquisition of the requisite language skills," Bârsan told World Finance. "For this reason, elementary language learning should be open to all asylum seekers and tolerated residents; work related language learning should be further developed also" (ibid.).

While such measures are a costly enterprise, particularly when factoring in millions of people, doing so is economically advantageous for 
the host nation. Contrary to common assumptions, refugees actually contribute more in taxes than they obtain in governmental support. There are further examples that illustrate that refugee workers actually increase wages for the local population. When Yugoslav refugees in Denmark began working in low-skilled jobs during the 1990s and the 2000s, rather than driving wages down as many expected, their presence made the economy more complex. Instead of filling such jobs, natives moved up the skills ladder to more specialized professions that were better paid and more productive. Then there is the case when Cuban refugees settled in Miami in 1980; they gave a major boost to the city's economy by providing unskilled labor in numerous industries, including hospitality, textile production and agriculture (ibid.).

In order to successfully assimilate refugees into local populations, facilitating employment is absolutely crucial. As Bârsan explained, this requires easing labor market restrictions, together with training and language learning opportunities for asylum seekers, and access to capital will enable new nationals to develop their own enterprises, which, as evidenced by Betts' study, enables entrepreneurship among refugees. To secure the political will needed to conduct such exercises, locals must be assured that they also stand to benefit. "Here, it is important that infrastructure and social services, from schools to hospitals to vocational training, are allocated to refugees and local populations simultaneously. Ensuring locals share in the benefits of service provision to refugees is as important in host countries in Africa and the Middle East as they are in Europe," Betts said (ibid.).

Statistics from the United Nations Department of Economic and Social Affairs, for instance, predict that the German work force will contract by 13 million people in the next forty years, and these spots will need to be filled to avoid economic slowdown. In response to this predicament, German state governments stated, in a joint declaration in early September 2015, that "[t]he vital question is, can we make good use of migrant potential and skills in our employment market and so achieve a successful immigrant society? Every euro we spend on training migrants is a euro to avoid a shortage of skilled labour and will later avoid many transfer payments" (Jarrin, 2015).

Besides providing a new and younger source of labor, Syrian refugees may contribute in other ways. According to a study released by Chmura Economics \& Analytics on the incorporation of refugees in Cleveland, $\mathrm{OH}$, USA, "refugees are highly motivated and wish to give back to their 
host country. Refugees are more likely to be entrepreneurial and enjoy higher rates of successful business ventures compared to natives" (ibid.).

Furthermore, this study claims that, generally speaking, "refugees do not take jobs away from natives, and the diversity of skilled immigration can positively impact the income and productivity of welcoming nations. At the local level, refugees provide increased demand for goods and services through their new purchasing power, and can be particularly revitalizing in communities that otherwise have a declining population" (ibid.).

Of course, all of these efforts will not be accomplished if the Syrian refugees are not granted appropriate asylum into the different European countries. In order to do so, all of the EU countries should begin to look at the crisis from a different angle, and the governments and people must be convinced of the huge benefits that they will get from the refugees' integration into their societies.

\section{What is asylum?}

Under EU rules, an asylum seeker has the right to food, first aid and shelter in a reception center. They should get an individual assessment of their needs. They may be granted asylum by the authorities at 'first instance'. If unsuccessful, they can appeal against the decision in court, and may win. Asylum seekers are supposed to be granted the right to work within nine months of arrival (ibid.).

In terms of asylum applications, the numbers varied from one European country to the other, as shown below.

The United Kingdom has received just over 7,000 applications for asylum from Syrian nationals, significantly fewer than European partners such as Austria $(18,647)$ and Sweden $(64,685)$. The UK seems to have been about as popular as its European neighbors such as France, which received 6,657 asylum applications over the period, and Spain, which received 5,554. The least popular European destinations were Iceland (14 asylum applications), Lithuania (28), Estonia (41), Latvia (89) and Ireland (101) (Bennett, 2015).

The EU countries have also been involved in dealing with the Syrian refugee crisis on other levels. Since October 24, 2012, the EU and its member states have provided approximately $€ 230$ million in humanitarian and other assistance to those affected by the Syrian crisis, both inside 
and outside the country, making the European Union the leading international donor. According to the European Commission, this amounts to more than $53 \%$ of the international response. Switzerland and Norway have likewise contributed considerable humanitarian assistance $(€ 10.7$ million as of September 4, 2012, and €2.95 million February 24, 2012 respectively) (Fargues, Fandrich, 2012/14).

The provision of aid, however, is only part of the EU's response to the Syrian refugee crisis - which is at the same time a political and humanitarian crisis. The EU has also worked to bring about a political transformation in Syria - i.e. the removal of Assad and the transition from authoritarianism to pluralistic and representative democracy - as the EU considers this approach to coincide with the interests of the Syrian people, and to be one of the solutions to the humanitarian crisis. The EU High Representative, Catherine Ashton, has steadfastly affirmed this approach in a statement on September 11, 2012, stating: "We have to do everything we possibly can to find ways to promote a political transition. And we have to be ready for the post-conflict moment and the period of transition towards what we want to see, which is, of course, democracy" (ibid.).

This multi-layered approach can also be differentiated according to external and internal responses. Externally, the EU response is to address immediate and future needs while also containing the crisis within its regional boundaries. European nations have been assisting the Syrian people by providing humanitarian assistance, whilst contemplating the implementation of a Regional Protection Programme to address the Syrian refugee crisis (a program that includes resettlement in the EU, but focuses mainly on addressing the crisis at a regional level). Internally, the response of EU member states is, on the one hand, to increase border security, and on the other, to grant asylum to a rising number of Syrians and to refrain from forcibly returning those ineligible for asylum status (ibid.).

Internationally, the EU is supporting several initiatives, including recurrent UN statements and resolutions which condemn the regime's actions and call for a cessation of violence. At the regional level, the EU is coordinating actions with the League of Arab States (LAS) in its political responses to the Syrian crisis by supporting the LAS observer mission commencing in December 2011, recommending imposition of LAS sanctions, supporting the Arab Plan of Action, and applauding LAS demands to Assad to end the violence and step aside (ibid.). 


\section{Conclusion}

The Syrian refugee crisis is a reality on the ground and a very influential human phenomenon that is affecting many countries around the world, and there is no other option for the world leaders but to attempt to deal with it in the most appropriate way. For Europeans, it is crucial that they try to approach the crisis from a different perspective, since mere force and rejection might not be the best of methods.

As described earlier in this article, the costs and burdens of the refugee crisis are undoubtedly huge in the short term, and dealing with millions of refugees is not an easy task. However, in the long term, the refugees could be a key future element to the formation of a better European economy, education, social life, work, industry and commerce if they are integrated well into the fabric of European society.

Europe already suffers from several issues, such as an aging population and low birth rates, as in Germany. Therefore, a quick boost is definitely needed, and the Syrian crisis provides just that. Human resources are the main constituent of any successful economy and development, especially if these resources include young workers. The relationship between the EU countries and the Syrian refugees must be that of mutual benefit and cooperation. In other words, EU governments should exert more efforts to try and provide the refugees with adequate accommodation, food, health services, jobs, education, etc. This will automatically encourage and motivate the refugees to contribute more and more to the host country's economy, development and well-being.

The future holds significant changes for Europe, and substantial growth if the EU countries manage to handle the Syrian refugee crisis properly and take advantage of the endless opportunities it can offer. After all, "every cloud has a silver lining."

\section{Bibliography}

Amnesty International (2015, September 4), Syria's Refugee Crisis in Numbers, Retrieved December 23, 2015.

BBC (2015, December 22), Migrant Crisis: Migration to Europe Explained in Graphics, Retrieved December 22, 2015.

Bennett A. (2015, September 3), Refugee crisis: How many Syrians have applied for asylum in Europe, and how many has Britain helped?, Retrieved December 23, 2015. 
Fargues P., Fandrich C. (2012/14), The European Response to the Syrian Refugee Crisis What Next?, Retrieved December 24, 2014.

Jarrin M. (2015, October 14), The Syrian Refugee Crisis: How Will It Impact Europe's Economies?, Retrieved December 23, 2015.

Kirk A. (2015, September 16), Refugee Crisis: How do European Countries'Attitudes Differ on Refugees?, Retrieved December 23, 2015.

Leadership.ng (2015, August 27), Why is EU Struggling with Migrants and Asylum?, Retrieved December 22, 2015.

Matsangou E. (2015, November 2), Refugees are an Economic Benefit, not Burden, to Europe, Retrieved December 23, 2015.

Peoples' Daily (2015, September 22), Why is EU Struggling with Migrants and Asylum Seekers?, Retrieved December 22, 2015.

Proctor K. (2015, September 15), Syria's refugees are a golden opportunity for Europe, Retrieved December 23, 2015.

Schwarz P. (2015, September 5), European Governments Treat Refugees as a Hostile Invasion Force, Retrieved December 23, 2015.

\section{Europa i uchodźcy syryjscy: wyzwania i możliwości}

\section{Streszczenie}

Od początku wojny w Syrii ogromna liczba syryjskich obywateli uciekła z ojczyzny, by uniknąć śmierci i zapewnić lepsze życie sobie i swoim dzieciom za granicą. Syryjscy uchodźcy ubiegali się o azyl w wielu krajach, ale to Europa była ich głównym celem. Bezbronne rodziny przeprawiły się przez rzeki, przemierzyły góry i równiny, stawiając czoła wszystkim możliwym zagrożeniom, by dotrzeć do Europy; wielu zmarło po drodze. Kierując się ku nieznanemu, uchodźcy nie wiedzieli, czego spodziewać się tam, dokąd zmierzają, jednak powrót nie wchodził w grę. Z drugiej strony tego procesu mamy państwa europejskie znajdujące się również pod dużą presją, by przyjmować uchodźców i radzić sobie z nimi. Reakcje i odpowiedź krajów europejskich na falę uchodźców były bardzo zróżnicowane: od Niemiec, które przyjmowały znaczące liczby syryjskich uchodźców, po Francję, Czechy i Wielką Brytanię, które witały ich raczej niechętnie. W niniejszym artykule omówiono i wyjaśniono podejście państw europejskich do kwestii rozwiązania syryjskiego kryzysu uchodźczego i stojące obecnie przed nimi wyzwania w kontekście konkretnych wydarzeń. Artykuł porusza kwestię relacji między syryjskimi uchodźcami a krajami europejskimi pod względem starań, jakie podjęła Europa, aby pomóc uchodźcom, a także wpływu, jaki uchodźcy mają lub będą mieli na różne aspekty życia w Europie.

Słowa kluczowe: uchodźcy syryjscy, Unia Europejska, migracja, azyl, kryzys, wojna domowa 
